\section{TREATMENT OF BACILLARY DYSENTERY}

\section{WITH SPECIAL REFERENCE TO STOSSTHERAPY WITH TETRACYCLINE}

BY

\author{
D. J. STOKER,* M.B., M.R.C.P. \\ Squadron Leader, Royal Air Force
}

From the Royal Air Force Hospital, Akrotiri, Cyprus

Treatment of bacillary dysentery remains a problem among British Forces in the Middle East, though less so than in the past. In 1959, with an incidence of 6.68 cases per thousand in the Royal Air Force abroad (Air Ministry, 1961), it was the commonest cause of admission to hospital after excluding injuries, acute upper respiratory disease, skin diseases, and non-specific gastroenteritis.

In the United Kingdom notifications have risen over the past 20 years, especially in regard to dysentery caused by Shigella sonnei.

Taylor (1959) has summarized the history of treatment of bacillary dysentery and reported the results of his own therapeutic trial in 332 cases at this hospital. $\mathrm{He}$ found that a six-day course of $125 \mathrm{~g}$. of phthalylsulphathiazole was more effective than supportive measures alone, but that treatment with a combination of absorbable sulphonamides and streptomycin ("streptotriad") gave still better clinical results.

Stosstherapy was the name given by Harnapp (1938) to the method of treatment of rickets by a single massive dose of vitamin D. Later, Gaisford (1951) used the term in the treatment of pneumonia with large single doses of sulphonamides. In Denmark and America the method has been called "shock-dose treatment," and it has been used both in infections and in infestations.

The present trial is complementary to that of Taylor (1959) and sets out, firstly, to compare the effectiveness of oral streptomycin treatment with and without sulphonamides, and, secondly, to see whether the period in hospital could be reduced by means of stosstherapy.

\section{Material and Methods}

A fairly mild variety of bacillary dysentery is found in Cyprus from about April to December. All adult male patients admitted to hospital with acute bacillary dysentery between April and January in two successive years were included in the trial, provided they had not received specific therapy. The trial involved 101 patients in 1959 and 91 in 1960.

Three diagnostic stool specimens from each patient admitted with diarrhoea were submitted to the laboratory. Each specimen was examined by direct microscopy, culture on desoxycholate citrate, fermentation of sugars, and slide agglutination with specific shigella antisera. The diagnosis of "clinical bacillary dysentery" (Fairley and Boyd, 1943) was based on the finding of large numbers of pus cells, red blood cells, and, to a less extent, macrophages and epithelial cells -that is, bacillary exudate-on direct microscopy. Isolation of shigellae resulted in the diagnosis of proved bacillary dysentery.

\footnotetext{
*Now at the Royal Air Force Hospital, Wroughton, near Swindon, Wilts.
}

Treatment was started when bacillary exudate was reported by the laboratory without necessarily waiting for the result of the culture. Shigellae were isolated from 45 cases in 1959 and 62 in 1960.

Comparison of Oral Streptomycin Alone and Combined with Soluble or Insoluble Sulphonamide

Three preparations of similar appearance were made, containing a dosage of: (A) streptomycin $2 \mathrm{~g}$./day; (B) streptomycin $1 \mathrm{~g}$./day and sulphaguanidine $8 \mathrm{~g}$./day ; (C) streptomycin $1 \mathrm{~g}$./day and sulphadimidine $4 \mathrm{~g}$./day. Treatment was divided into four doses during the day and given for five days. The identity of each preparation was known only to the pharmacist, and successive patients were allocated to $\mathrm{A}, \mathrm{B}$, or $\mathrm{C}$ treatment groups. The day after completion of treatment was a rest day, and laboratory examination of six successive daily stool specimens was then carried out before the patient was allowed to leave hospital. In addition, mist. kaolin. et morph. B.P. was given to any patient, in the usual dosage, as often as required.

Results.-All patients improved subjectively on bed rest and supportive and specific therapy. The only truly objective indication of cure was the demonstration that all clearance stools were free from bacillary exudate on direct microscopy and that no pathogens were isolated on culture. Relapse rates are shown in Table $I$. The lower relapse rate on treatment with preparation $C$ compared with preparation $\mathbf{A}$ is statistically significant when all cases are considered, but scarcely significant

\begin{tabular}{|c|c|c|c|c|c|c|c|c|c|}
\hline \multirow{3}{*}{ Organism } & \multicolumn{3}{|c|}{ Treatment A } & \multicolumn{3}{|c|}{ Treatment B } & \multicolumn{3}{|c|}{ Treatment $\mathbf{C}$} \\
\hline & \multirow{2}{*}{ Cases } & \multicolumn{2}{|c|}{ Relapses } & \multirow{2}{*}{ Cases } & \multicolumn{2}{|c|}{ Relapses } & \multirow{2}{*}{ Cases } & \multicolumn{2}{|c|}{ Relapses } \\
\hline & & No. & $\%$ & & No. & $\%$ & & No. & $\%$ \\
\hline $\begin{array}{l}\text { Sh. flexneri III } \\
\text { ", ", IV } \\
\text { "III ", I and } \\
\text { Sh. boydii IV } \\
\text {, sonnei }\end{array}$ & $\begin{array}{r}3 \\
2 \\
-1 \\
12\end{array}$ & $\begin{array}{r}1 \\
1 \\
-0 \\
4\end{array}$ & $\begin{array}{l}33 \cdot 3 \\
50 \\
-0 \\
33 \cdot 3\end{array}$ & $\begin{array}{l}3 \\
1 \\
1 \\
9\end{array}$ & $\begin{array}{l}1 \\
0 \\
0 \\
1\end{array}$ & $\begin{array}{l}33 \cdot 3 \\
0 \\
\frac{0}{11 \cdot 1}\end{array}$ & $\begin{array}{r}2 \\
1 \\
-2 \\
8\end{array}$ & $\begin{array}{l}0 \\
0 \\
-1 \\
0\end{array}$ & $\begin{array}{c}0 \\
0 \\
50 \\
0\end{array}$ \\
\hline $\begin{array}{l}\text { All shigellae . } \\
\text { Clinical dysentery }\end{array}$ & $\begin{array}{l}18 \\
16\end{array}$ & $\begin{array}{l}6 \\
0\end{array}$ & $\begin{array}{c}33 \cdot 3 \\
0\end{array}$ & $\begin{array}{l}14 \\
20\end{array}$ & $\begin{array}{l}2 \\
1\end{array}$ & $\frac{14 \cdot 3}{5}$ & $\begin{array}{l}13 \\
20\end{array}$ & $\begin{array}{l}1 \\
0\end{array}$ & $\begin{array}{l}7 \cdot 7 \\
0\end{array}$ \\
\hline All cases & 34 & 6 & $17 \cdot 6$ & 34 & 3 & $8 \cdot 9$ & 33 & 1 & $3 \cdot 0$ \\
\hline
\end{tabular}

(difference divided by the standard error $=1.92$ ) when proved cases only are considered. No significant difference is shown when the other groups are compared. Any patient whose dysentery relapsed was given a further course of the same treatment received initially and no second relapse was encountered.

\section{Comparison of Streptomycin and Sulphadimidine Mixture with Tetracycline Stosstherapy}

In 1960 alternate dysentery patients were given either preparation $\mathrm{C}$ or a single dose of $2.5 \mathrm{~g}$. (ten 250-mg. tablets) of tetracycline. Criteria and management were as in the previous year, except that, in the tetracycline group only, two rest days were given before beginning to collect clearance stool specimens. This was because it was felt on theoretical grounds that longer than 24 hours was needed to allow the bowel inflammation to settle and for the large dose of tetracycline to be excreted.

Results.-Relapse rates are shown in Table II, and although there were fewer relapses when using tetracycline this was not statistically significant. However, it is clear that the results of using such stosstherapy are 
TABLE II-Relapse Rates, 1960

\begin{tabular}{|c|c|c|c|c|c|c|c|}
\hline \multirow{3}{*}{ Organism } & & \multicolumn{3}{|c|}{$\begin{array}{l}\text { Streptomycin/ } \\
\text { Sulphadimidine }\end{array}$} & \multicolumn{3}{|c|}{ Tetracycline } \\
\hline & & \multirow{2}{*}{ Cases } & \multicolumn{2}{|c|}{ Relapses } & \multirow{2}{*}{ Cases } & \multicolumn{2}{|c|}{ Relapses } \\
\hline & & & No. & $\%$ & & No. & $\%$ \\
\hline 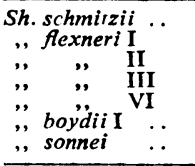 & $\begin{array}{l}\ldots \\
\cdots \\
\cdots \\
\cdots \\
\cdots\end{array}$ & $\begin{array}{r}-1 \\
1 \\
7 \\
7 \\
17\end{array}$ & $\begin{array}{l}-0 \\
0 \\
4 \\
0 \\
2\end{array}$ & $\begin{array}{c}\overline{0} \\
0 \\
5 \overline{59 \cdot 1} \\
0 \\
11 \cdot 8\end{array}$ & $\begin{array}{r}1 \\
1 \\
1 \\
3 \\
7 \\
3 \\
13\end{array}$ & $\begin{array}{l}0 \\
0 \\
0 \\
1 \\
0 \\
0 \\
2\end{array}$ & $\begin{array}{c}0 \\
0 \\
0 \\
33 \cdot 3 \\
0 \\
0 \\
15 \cdot 4\end{array}$ \\
\hline $\begin{array}{l}\text { All shigellae ... } \\
\text { Clinical dysentery }\end{array}$ & 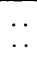 & $\begin{array}{l}33 \\
13\end{array}$ & $\begin{array}{l}6 \\
0\end{array}$ & $\underset{0}{18 \cdot 2}$ & $\begin{array}{l}29 \\
16\end{array}$ & $\begin{array}{l}3 \\
0\end{array}$ & $\begin{array}{c}10 \cdot 3 \\
0\end{array}$ \\
\hline All cases & .. & 46 & 6 & $13 \cdot 0$ & 45 & 3 & $6 \cdot 7$ \\
\hline
\end{tabular}

as good as if not better than a more orthodox regime of therapy using streptomycin alone. More relapses were apparent than in the previous year, and this may reflect the altered distribution of shigellae, especially in respect of Sh. flexneri VI (Table II). No side-effects were noted from the administration of 10 tablets of tetracycline as a single dose. One patient vomited the tablets immediately after their ingestion, and it became the practice to allow the tablets to be taken over a period of about an hour if the patient was complaining of nausea.

\section{Discussion}

The comparison of treatments for bacillary dysentery is often difficult as the incidence of the different organisms varies from year to year. Table III shows the altering pattern in parts of the Middle East and includes the figures of Boyd (1946) and Taylor (1959). Although in Cyprus, as in other parts of the world, $S h$. sonnei is encountered most often, the other species of Shigella, especially Sh. flexneri, remains of considerable importance.

TABLE III.-Incidence of Shigellae in Dysentery in Middle

\begin{tabular}{|c|c|c|c|c|}
\hline & & $\begin{array}{c}1940-3 \\
\text { (Boyd, 1946) }\end{array}$ & $\begin{array}{c}1957-8 \\
\text { (Taylor, 1959) }\end{array}$ & $\begin{array}{c}1959-60 \\
\text { (Present Series) }\end{array}$ \\
\hline $\begin{array}{l}\text { Sh. shigae } \\
\text { ", schmitzi } \\
\text { ", flexneri } \\
\text { boydii . . sonnei . } \\
\text { Ünidentified }\end{array}$ & $\begin{array}{l}. \\
\because \\
\because \\
.\end{array}$ & $\begin{array}{r}18.9 \% \\
6 \cdot 7 \% \\
61 \cdot 6 \% \\
7 \cdot 4 \% \\
55 \%\end{array}$ & $\begin{array}{l}\bar{Z} \\
49 \cdot 3 \% \\
1.4 \% \\
49 \cdot 3 \%\end{array}$ & $\begin{array}{l}0 . \overline{9} \% \\
31 \cdot 8 \% \\
12.1 \% \\
55.1 \% \\
\end{array}$ \\
\hline
\end{tabular}

Taylor (1959) showed that a cure rate of over $80 \%$ could be achieved in acute bacillary dysentery without any specific therapy. His criterion of cure was the same as in the present series-that is, negative examination by the laboratory of six daily clearance stools. To improve on this result an effective treatment must produce a cure rate of over $90 \%$ and cause no unwelcome side-effects. Sangster (1956) showed that a five-day course of oral streptomycin ( $2 \mathrm{~g}$. daily in adults) gave an $80 \%$ cure rate in 1,474 patients and that a second course raised this total to $95 \%$, although surveillance in most cases was continued until only three consecutive bacteriological examinations of faeces had proved negative. However, there were indications that bacterial resistance would in time render the treatment less effective. This had also been the finding of Klein and Kimmelman (1946), and on laboratory evidence they recommended that streptomycin would be more effective if combined with sulphadiazine.

The tetracyclines have proved most effective (Garfinkel et al., 1953 ; Abbott and Parry, 1955 ; McKendrick and Medlock, 1958), but hazards such as fatal staphylococcal infection (Hay and McKenzie, 1954) and other less severe but nevertheless trowblesome cross-infections (Murphy, 1955) cannot be ignored.

The rationale of stosstherapy in infection depends upon achieving a very high and early concentration of the therapeutic agent in the blood causing wholesale destruction of the invading organism, the "therapia sterilisans magna." In the treatment of bowel infection there is, in addition, the continuing local effect of the agent while it remains in the alimentary tract. As streptomycin is not appreciably absorbed from the gastro-intestinal tract, tetracycline was used for stosstherapy. Finland, Purcell, et al. (1954) showed that tetracycline was more active in vitro against Sh. sonnei than either oxytetracycline or chlortetracycline, and in addition it produces fewer side-effects than its analogues (Welch, 1954).

Time lost by a person contracting dysentery may be considerable if effective control is imposed to prevent the convalescent carrier state. It is not possible to reduce with safety the time for clearance after dysentery, as relapses may occur as late as the sixth day after treatment (Table IV).

TABLE IV.-Day of Relapse (All Cases 1959-60)

\begin{tabular}{|c|c|c|c|c|c|c|}
\hline Clearance day ... & 1 & 2 & 3 & 4 & 5 & 6 \\
\hline Number relapsed & 7 & 4 & 0 & 2 & 2 & 2 \\
\hline
\end{tabular}

The mean hospital stay using the streptomycin and sulphadimidine mixture was 13 days, whereas with tetracycline stosstherapy it was reduced to nine days. This compares favourably with an average stay of 13.4 days in the series of McKendrick and Medlock (1958), who required only three negative stool cultures as their criterion of cure.

The short duration of treatment makes complications due to tetracycline unlikely. There were none in this small series and this may be related to the observations of Finland, Grigsby, et al. (1954) that untoward effects from the tetracyclines were increased as the interval between successive doses was narrowed. The basic cost of the tetracycline treatment $(2.5 \mathrm{~g}$. $)$ is just under 12 shillings - twice the cost of five days' treatment with the streptomycin and sulphadimidine mixture. This greater expense is more than offset by the saving of working time and hospital costs.

\section{Summary}

A trial of treatment for acute bacillary dysentery is described in which a mixture of streptomycin and soluble sulphonamide gave a cure rate of $97 \%$ after a five-day course. This was better than that for a mixture of streptomycin and poorly soluble sulphonamide and significantly better than streptomycin alone in twice the dosage.

In a second trial, single-dose treatment (stosstherapy) with $2.5 \mathrm{~g}$. of tetracycline gave results as good as the streptomycin and sulphadimidine mixture, but with a reduction of four days in the duration of treatment of each patient, reflecting a considerable saving of time and money.

I thank Flight Lieutenant A. W. McCracken for his help with the pathology and for his encouragement at all times; the nursing and laboratory staff for their co-operation, without which this work could not have been done; and the Director-General of the Royal Air Force Medical Services for permission to publish. 


\section{REFERENCES}

Abbott, J. D., and Parry, H. E. (1955). Lancet, 1, 16

Air Ministry" (1961). Report on the Health of the Royal Air Force for the Year 1959. H.M.S.O., London.

Boyd, J. S. K. (1946). J. Path. Bact., 58, 237.

Fairley, N. H., and Boyd, J. S. K. (1943). Trans. roy. Soc. trop.

Med. Hyg., 36, 253.
Finland, M., Grigsby, M. E., and Haight, T. H. (1954). Arch. intern. Med., 93, 23.

Purcell, E. M., Wright, S. S., Love, B. D., jun., Mou, T. W., and Kass, E. H. (1954). J. Amer. med. Ass.,
Gaisford, W. (1951). In Modern Trends in Paediatrics, edited by L. Parsons, p. 375. Butterworth, London.

Garfinkel, B. T., Martin, G. M., Watt, J., Payne, F. J., Mason, R. P., and Hardy, A. V. (1953). J. Amer. med. Ass., 151. 1157.

Harnapp, G. O. (1938). Klin.Wschr., 17, 390

Hay, P., and McKenzie, P. (1954). Lancet, 1, 945.

Klein, M., and Kimmelman, L.J. (1946), J. Bact, 51, 581.

McKendrick, G. D. W., and Medlock, J. M. (1958). Publ. Hlth (Lond.). 72, 25.

Murphy, E. F. (1955). Irish J. med. Sci., p. 523.

Sangster, G. (1956). Lancet, 1, 723.

Taylor, P. J. (1959). Brit. med. J. 2, 9.

Welch, H. (1954). Antibiot. and Chemother., 4, 375.

\title{
LEPTOSPIROSIS
}

\section{A COMPARISON OF SYMPTOMATIC AND PENICILLIN THERAPY}

\author{
BY
}

\section{R. S. KOCEN,* M.B., M.R.C.P.}

Formerly Junior Specialist in Medicine and Officer in Charge, Medical Division, British Military Hospital, Taiping, Malaya

The efficacy of various antibiotics in the treatment of leptospirosis in man has continued to be questioned, and three recent reports on their use in military personnel in Malaya have aroused some controversy. Fairburn and Semple (1956) found no significant difference between the duration of symptoms, signs, pyrexia, and the incidence of complications in three groups treated with penicillin $(600,000$ units six-hourly for at least five days), chloramphenicol ( $0.5 \mathrm{~g}$. six-hourly for at least five days), and symptomatically only, even when the antibiotics were started within four days of onset of illness. Mackay-Dick and Robinson (1957), in 84 cases treated without controls, found that the duration of fever was reduced to about 18 hours if penicillin $(600,000$ units four-hourly for 24 hours, then six-hourly for six days) was administered within six days of onset. Ross Russell (1958), in a controlled trial using oxytetracycline $(1.5 \mathrm{~g}$., followed by $0.5 \mathrm{~g}$. six-hourly for at least five days), found that it reduced the duration of fever and of symptoms but did not affect the incidence of renal and hepatic complications. These reports gave rise to some conflicting correspordence (Clein, 1956; MackayDick and Robinson, 1959 ; Cook, 1959 ; Semple, 1959 ; Doherty, 1960; Fairburn and Semple, 1960) which re-emphasized the difficulties in assessing the effects of treatment on a disease usually short-lasting and relatively uncomplicated without any specific therapy but with an extremely wide spectrum of severity and, in Malaya, caused by many different leptospiral serotypes (Turner et al., 1959).

The present article compares certain aspects of the disease in 33 cases of leptospirosis treated symptomatically and in 28 treated with penicillin.

\section{Material and Methods}

The two groups were part of 82 cases treated by one observer between January, 1959, and May, 1960, in one hospital; all were later confirmed either by a positive blood culture or serologically. Twenty-one cases were excluded because of coexistent disease requiring other treatment, inadequate follow-up for administrative reasons, or antibiotic therapy administered prior to admission to hospital. During the first nine months of that period soluble penicillin was given routinely intramuscularly as follows: 600,000 units four-hourly for

*Now at the Middlesex Hospital, London.
24 hours, then six-hourly for four days (total 13.2 million units); 24 cases were so treated during that period and four others later ; these latter were treated later because of administrative errors in three and an unusual presentation in one. During this period seven cases were treated symptomatically only, either because of relatively late presentation in hospital or because of uncertainty of the diagnosis. The remaining 26 cases were treated symptomatically as part of a definite policy during the second eight months of that period.

All the patients were seen at least once a day and more often during the acute stage of the illness, and any changes in signs were noted. Urinalysis was performed on admission and again at intervals later if normal at first. Serum bilirubin was estimated only in cases showing clinical icterus, and the upper limit of normal was taken as $1.5 \mathrm{mg} . / 100 \mathrm{ml}$. The temperature was regarded as having returned to normal when it had remained below $99^{\circ} \mathrm{F}$. $\left(37.2^{\circ} \mathrm{C}\right.$.) for over 24 hours, any subsequent rise being noted as an "after-peak."

\section{Results}

Table I shows the duration of illness before treatment, the duration of pyrexia after treatment was started, and the total duration of the pyrexia; cases have been subdivided according to whether treatment was started within or after four days from onset. The mean times

TABLE I.-Duration of Pyrexia (Mean and Standard Deviation in Days) Before and After the Start of Appropriate Therapy,
and Its Total Duration

\begin{tabular}{|c|c|c|c|c|c|c|c|c|}
\hline \multirow{3}{*}{ Clinical Phase } & \multicolumn{4}{|c|}{$\begin{array}{l}\text { Cases Treated within } \\
4 \text { Days of Onset }\end{array}$} & \multicolumn{4}{|c|}{$\begin{array}{l}\text { Cases Treated after } \\
4 \text { Days from Onset }\end{array}$} \\
\hline & \multicolumn{2}{|c|}{$\begin{array}{c}\text { Penicillin } \\
\text { (15 Cases) }\end{array}$} & \multicolumn{2}{|c|}{$\begin{array}{c}\text { Symptomatic } \\
\text { (23 Cases) }\end{array}$} & \multicolumn{2}{|c|}{$\begin{array}{c}\text { Penicillin } \\
\text { (13 Cases) }\end{array}$} & \multicolumn{2}{|c|}{$\begin{array}{l}\text { Symptomatic } \\
\text { (10 Cases) }\end{array}$} \\
\hline & Mean & \pm S.D. & Mean & \pm S.D. & Mean & \pm S.D. & Mean & 七S.D. \\
\hline $\begin{array}{l}\text { Before treatment } \\
\text { After }\end{array}$ & $\begin{array}{l}3 \cdot 4 \\
1 \cdot 3 \\
\end{array}$ & $\begin{array}{l}0.9 \\
0.6\end{array}$ & $\begin{array}{l}3 \cdot 4 \\
5 \cdot 7 \\
\end{array}$ & $\begin{array}{l}0.9 \\
2.5 \\
\end{array}$ & $\begin{array}{l}6 \cdot 0 \\
1 \cdot 4 \\
\end{array}$ & $\begin{array}{l}0.9 \\
0.7\end{array}$ & $\begin{array}{l}5 \cdot 3 \\
4 \cdot 3\end{array}$ & $\begin{array}{l}0.5 \\
1.9\end{array}$ \\
\hline $\begin{array}{c}\text { Total duration of } \\
\text { pyrexia }\end{array}$ & $3 \cdot 7$ & 1.0 & $8 \cdot 1$ & $2 \cdot 5$ & $6 \cdot 4$ & 1.7 & $8 \cdot 6$ & 1.9 \\
\hline
\end{tabular}
* The last day of the pretreatment period and the first day of treatment

of admission for cases treated with penicillin were 2.9 and 4.2 days respectively in those subgroups, while in patients treated symptomatically the time of admission was taken as the time when treatment was startedthat is 3.4 and 5.3 days respectively. The results show that in the symptomatically treated cases the pyrexia 